\title{
Potential application of biodrying to treat solid waste
}

\author{
Badrus Zaman ${ }^{1}$, Wiharyanto Oktiawan ${ }^{1}$, Mochtar Hadiwidodo ${ }^{1}$, Endro Sutrisno ${ }^{1}$, Purwono ${ }^{1,}{ }^{*}$, Irawan Wisnu Wardana ${ }^{1}$ \\ Department of Environmental Engineering, Faculty of Engineering, Diponegoro University, Semarang - Indonesia
}

\begin{abstract}
The generation of solid waste around the world creates problems if not properly managed. The method of processing solid waste by burning or landfill is currently not optimal. The availability of land where the final processing (TPA) is critical, looking for a new TPA alternative will be difficult and expensive, especially in big cities. The processing of solid waste using bio drying technology has the potential to produce renewable energy and prevention of climate change. Solid waste processing products can serve as Refuse Derived Fuel (RDF), reduce water content of solid waste, meningkatkan kualitas lindi and increase the amount of recycled solid waste that is not completely separated from home. Biodrying technology is capable of enhancing the partial disintegration and hydrolys is of macromolecule organic compounds (such as C-Organic, cellulose, hemicellulose, lignin, total nitrogen). The application of biodrying has the potential to reduce greenhouse gas emissions such as carbon dioxide $\left(\mathrm{CO}_{2}\right)$, methane $\left(\mathrm{CH}_{4}\right)$, and dinitrooksida $\left(\mathrm{N}_{2} \mathrm{O}\right)$. These gases cause global warming.
\end{abstract}

\section{Introduction}

Solid waste generation worldwide can cause problems if not properly managed. Solid waste management with a decentralized system in residential areas is able to reduce solid waste well. Intensity and roving activity produce many biodegradable solid wastes that must be managed to avoid negative impacts on the environment [1]. The interesting technologies of recent years are Mechanical Biological Treatment (MBT) and Biological Mechanical Treatment (BMT). Biodrying (Biological Drying) where solid wastes are readily bio compatible biologicalmechanical [2].

Biodrying rework process (biological access). In practice, the biodiesel reactor entrusts high-level solid waste that has been chopped up and produces the output of biodrified waste that will undergo further mechanical processes. The heat generated from the aerobic decomposition process by using excess air serves to dry out solid waste [3].

The results of processing using biodiesel can serve as fuel substitute fuel (RDF) which is fuel produced from various types of waste such as waste, industrial waste or commercial waste. RDF can be used as a coal substitute [2]. The most obvious uses of the bio drying process are the decrease in odor, volume, and weight of waste, which can improve dental, transport and solid waste disposal at the time of large solid waste volumes. Furthermore, biodiesel has also become an effective way to eliminate some pathogenic microorganisms.

The bio-drying process has the potential to generate air emissions derived from aeration and aerobic decomposition processes such as Volatile Organic Compounds (VOCs), carbon dioxide $\left(\mathrm{CO}_{2}\right)$, methane
$\left(\mathrm{CH}_{4}\right)$, and dinitroxide $\left(\mathrm{N}_{2} \mathrm{O}\right)$ [4]. The gas contributes to global warming or global warming which is a phenomenon of increasing global temperature from year to year due to the occurrence of the greenhouse effect (greenhouse effect). According to [5], the global average earth temperature increases over the last 100 years with an increase temperature of $0.74 \pm 0.18^{\circ} \mathrm{C}$ caused by increased emissions of gases such as carbon dioxide $\left(\mathrm{CO}_{2}\right)$, methane $\left(\mathrm{CH}_{4}\right)$, dinitroxide $\left(\mathrm{N}_{2} \mathrm{O}\right)$ And chlorofluorocarbons (CFCs) or can be called GHGs so that solar energy is trapped in the Earth's atmosphere.

The following discussion is a potential application of bio-drying to treat solid waste, especially waste water content and Municipal Solid Waste (MSW).

\section{Refuse Derived Fuel (RDF)}

In the bio-drying process, the heat generated from the aerobic decomposition process of organic compounds combined with excess air serves to drain waste [3]. The result of processing using bio-drying can serve as Refuse Derived Fuel (RDF) which is fuel produced from various types of solid waste such as urban waste, industrial waste or commercial waste. RDF can be used as a substitute for coal [6-9]. According to [10], the criteria of a material can be used as fuel can be seen from chemical properties (eg elemental analysis, trace analysis, ash analysis), mechanics (eg bulk density, particle size / particle size distribution), calories (eg LHV, adiabatic Combustion temperature, minimum air consumption) and the reaction (Volatile Organic Compounds, emission gas). In practice, inert solid waste must be separated first, enriching the organic material and increasing the

\footnotetext{
Corresponding author: purwono.ga@gmail.com
} 
lower heating value (LHV). The final LHV value of the bio-drying product is higher than the initial MSW LHV [1]. For example comparison of LHV values in some fuels such as Coke 29.5 MJ/kg, Wood chips 12.0 MJ / $\mathrm{kg}$, RDF $11.7 \mathrm{MJ} / \mathrm{kg}$. According to [11] RDF requirements are (1) Calorific value on average at 15 GJ/ton, (2) Moisture content $<20 \%$ mass, (3) Chlorine content $<1 \%$.

\section{Water Content and Leachate Quality}

The bio-drying process has an impact on the decrease of water content due to high temperature and adequate ventilation. According to [12-13], proper aeration control (eg, debit and direction of flow) and temperature can lower water levels efficiently $(66.7 \%$ of the initial moisture content). Solid waste can be burned properly when the water content is about $20 \%$. Aerobic biodrying technology principle is to encourage evaporation using the energy generated as a result of the degradation of organic matter. When the water content ratio of the solid waste of the biodegradable organic material is too high, then the heat arising is not enough to evaporate the water. On the other hand, solid waste will decay due to high water content. The amount of water caused by spoilage (leachate) is limited by a cell wall or a crushed membrane. Their aeration increasing disintegration and partial hydrolysis of organic compounds macromolecules (such as C-Organic, cellulose, hemicellulose, lignin, total nitrogen [14]. The process bio-drying solid waste with high moisture content they produce leachate. According to [15 ], [16] the parameters of $\mathrm{pH}$, Chemical Oxygen Demand (COD), Biological Oxygen Demand (BOD), ammonium $\left(\mathrm{NH}_{4}-\mathrm{N}\right)$, nitrate $\left(\mathrm{NO}_{3}-\mathrm{N}\right)$, and the volume of leachate is much lower than without bio-drying.

\section{Sorting}

The main principle for every country related to solid waste management is prevention. The second principle is recycling (recycle) and energy production (energy production). The final principle is the disposal of solid waste without recycling and generating energy. Biodrying technology supports sustainable environment related to solid waste processing. The amount of solid waste that will enter the final processing place (TPA) will substantially decrease. Significantly increase the amount of recycled solid waste by separating materials (glass, inert, iron and non ferrous metals) that are not completely separated at home [12], [17], [18].

The concept of MBT consists of three stages. Pretreatment stage is shredders. The second stage is biodrying with the aim of drying solid waste. Solid waste is placed in the pile, covered with a membrane and aerated for approximately 3 to 4 weeks. The purpose of this step is to drain the water content of $<20 \%$ mass $\%$. Posttreatment stage of separation of ferrous metals, sieves, density separators, inert screens, manual sorting, reshredders and storage. The purpose of this step is to sort out recyclables that can be treated efficiently and RDF (particle size $\leq 50 \mathrm{~mm}$, moisture content $\leq 20 \%$ ) of waste and to reduce the amount of waste residue for disposal (amount for disposal should be $\leq 20 \%$ ) [11].

\section{Gas Emission}

In the bio-drying process, volatile organic compounds (VOCs) such as foul-smelling (sulfuric), aromatic, chlorine, terpene and ketones will be released into the air. This VOC became one of the main problems with air pollution [4]. Many previous studies have suggested that VOCs and/or odors will be released into the air derived from solid waste aerobic composting (MSW, bio waste, fruits, food scraps, mixed paper, and yard waste) at various scales [19], [20], [21], [22]. Non-methane organic compounds during the decomposition of solid waste under aerobic and anaerobic conditions have been compared by [23]. Whereas [18] states that foul-smelling sulfur compounds and terpene compounds are the most widely released compounds into the air in the early phases of bio-drying, whereas aromatic and ketone compounds are released later during the bio-drying process. The ammonia emissions resulting from the conversion of organic matter biologically can be absorbed using the acidic compound to form ammonium sulphate solution which serves as a substitute for artificial fertilizer [24]. Gases causing the greenhouse effect have not been much discussed by researchers. The gases are carbon dioxide $\left(\mathrm{CO}_{2}\right)$, methane $\left(\mathrm{CH}_{4}\right)$, and dinitrooksida $\left(\mathrm{N}_{2} \mathrm{O}\right)$. However, according to [25], methane gas probably will not be formed because in the process of bio-drying is the aerobic process.

\section{Conclusion}

The processing of solid waste using bio drying technology has the potential to produce renewable energy as Refuse Derived Fuel (RDF), reduce water content of solid waste, Improve leachate quality and increase the amount of recycled solid waste that is not completely separated from home. Biodrying technology is capable of enhancing the partial disintegration and hydrolysis of macromolecule organic compounds. The application of biodrying has the potential to reduce greenhouse gas emissions such as carbon dioxide $\left(\mathrm{CO}_{2}\right)$, no methane $\left(\mathrm{CH}_{4}\right)$, and dinitrooksida $\left(\mathrm{N}_{2} \mathrm{O}\right)$. Gases causing the greenhouse effect have not been much discussed by researchers.

\section{The acknowledgments}

Thank you to DRPM DIKTI for funding this research through PUPT grant with contract number 007 / SP2H / DRPM / V / 2017 financing year 2017 


\section{References}

1. E. C. Rada, M. Ragazzi, V. Panaitescu, Sci. Bull., Series D, Vol. 71, Iss. 4, (2009).

2. E. Rada, and M. Ragazzi, Biological Treatment of Solid Waste: Enhancing Sustainability, 219, (2015).

3. C.A. Velis, P.J. Longhurst, G.H. Drew, R. Smith, S.J.T. Pollard. 2009. UK: Bioresource Technology 100, 2747-2761, (2009)

4. He, P J, Shao L M, Qu X, Li G J, Lee D J, Chemosphere, 59(6): 837-844, (2005)

5. Muhi, A. Hanapiah, Pemanasan Global (Global Warming) (Skripsi). Institut Pemerintahan Dalam Negeri (IPDN). Jatinangor, (2011)

6. E. C. Rada, I. A. Istrate, M. Ragazzi, Environmental Technology, Vol. 30, No. 7, 651-661, (2009).

7. E. C. Rada, M. Ragazzi, V. Panaitescu, T. Apostol, Stintific Buletin, seria C: Electrical Engineering, vol 67, nr. 2, 69-76, (2005).

8. Gleis Markus, Technische Lösungen zur Abfallentsorgung in Europa -Strategien und Erfahrungen aus 20 Jahren, Proceedings of Tagung:Gesellschaft, Umweltund Gesundheit, Ecocenter Bolzano, (2009).

9. Elena Cristina Rada, $\mathrm{PhD}$, Biological Treatment of Solid Waste Enhancing Sustainability. Canada: Apple Academic Press, Inc, (2016).

10. M. Beckmann, M. Pohl, D. Bernhard, K. Gebauer, Waste Management \& Research. vol. 30, S. 354 369, April (2012)

11. Virginie Herbst, Dr. Ludwig Streff, Andrea Humeniuk, New ways to make MBT sustainable Case Study - Bio-drying for RDF production in Sulaimaniyah, Iraq, 2013. Germany: Ingenieurgesellschaft Prof. Czurda und Partner mbH (ICP), (201

12. F. Adani, D. Baido, E. Calcaterra, and P. Genevini, Bioresource technology, 83(3), 173-179, (2002).
13. M. Sugni, E. Calcaterra, F. Adani, Bioresource Technology, 96: 1331-1337, (2005)

14. P. H. L. Nguyen, P, Kuruparan, C. Visanathan, Bioresour Technol, 98(2): 380-387, (2007)

15. W. Oktiawan, Purwono, H. Mochtar, R. Arya, Penerapan teknologi biodrying dalam pengolahan sampah hight water content menuju zero leachate. Prosiding Seminar Nasional Lahan Basah Tahun 2016 Jilid 2: 572-576, (2006)

16. H.N. Rahmawati, Sudarno, Purwono, Skripsi. Departemen Teknik Lingkungan, Fakultas Teknik, Universitas Diponegoro, (2016)

17. R. M. Negoi, M. Ragazzi, T. Apostol, E. C. Rada, and C. Marculescu, UPB Sci. Bull. Serie C, 71, 193204, (2009).

18. H. L. Choi, T. L. Richard, and H. K. Ahn, Compost Science \& Utilization, 9(4), 303-311, (2001).

19. K. S. Das, Odor related issues in commercial composting. Workshop Presented at the Y2K Composting in the Southeast Conference \& Expo. October 9, 2000, Charlottesville, VA, (2000)

20. B. D. Eitzer, Environmental Science \& Technology, 29: 896-902. Germany, (1995)

21. P. Pierucci, E. Porazzi, M. P. Martinez, F. Adani, C. Carati, F. M. Rubino et al., Chemosphere, 59: 423 430, (2005)

22. X. M. Wu .T. Wang, Environmental Science \& Technology, 42: 3265-3270, (2008)

23. B .F. Staley, Xu F X, S. I. Cowie, M. A. Barlaz, G. R. Hater, Environmental Science \& Technology, 40: 5984-5991, (2006)

24. Winkler MK1, MH. Bennenbroek, FH. Horstink, van Loosdrecht MC, van de Pol GJ. 2013. Bioresour Technol, Nov;147:124-9, (2013)

25. G. Tchobanoglous, and F. Kreith, Handbook of Solid Waste Management, 2nd Ed., McGraw-Hill, (2000) 